\title{
Disinformation in the New Media System - Characteristics, Forms, Reasons for its Dissemination and Potential Means of Tackling the Issue
}

\author{
Tomislav Levak*
}

\section{SUMMARY}

This paper aims to explain the phenomenon of disinformation and its impact. Furthermore, it aims to point out the magnitude and seriousness of the problem, as well as the importance of joint action of all social structures in solving it.

The design, production, and dissemination (mainly orally) of untrue and inaccurate information and news for various purposes have been recorded since ancient times. After the invention of the printing machine, their continuous reproduction and distribution began in written form, which also enabled them to have a stronger impact, longer duration, and greater reach. Thanks to the development of the media, especially the mass media such as newspapers, radio, and television, information and news spread faster, more easily and farther, but at the same time, disinformation began to appear in the public sphere more often. Due to the strong development of technology and the emergence of new digital media, primarily the Internet, social networks, and communication platforms, as global communication phenomena, this problem has reached worrying, and often dangerous, levels in the current digital age and the new media system. According to recent indicators and research, the situation is deteriorating.

Although the number of papers and the amount of research on this topic has significantly increased in Europe and the world in recent years, it is a complex issue which is still not sufficiently addressed in the scientific discourse. There-

\footnotetext{
*Tomislav Levak, MA in Cultural Studies and Media Culture, The Academy of Arts and Culture in Osijek, Josip Juraj Strossmayer University of Osijek, Ulica kralja Petra Svačića 1/f, 31000 Osijek, Croatia e-mail: tomo.levak@gmail.com,tlevak@aukos.hr
} 
fore, this paper attempts to provide a clear insight into the definitions and characteristics of disinformation, as a concept that was officially adopted at the European Union level, for the purpose of denoting the phenomenon, along with related and similar terms such as fake news, misinformation, malinformation, information disorder, information pollution, alternative facts and others. This is done by including the appropriate theoretical background and the results of a series of relevant previous research studies in order to briefly present the historical development and known cases of disinformation, as well as the causes, reasons, consequences, and the most sensitive spheres of their production and dissemination in modern society. The methods for recognizing, preventing, and combating disinformation established thus far are also presented. In addition, new measures for their suppression are also proposed.

Keywords: disinformation, new media, fake news, information disorder, new media system, digital age, tackling disinformation

\section{Introduction:}

\section{disinformation and fake news through history}

Designing, producing and disseminating untrue and inaccurate information and news for various purposes, most often for the purpose of propaganda or manipulation, is a phenomenon that is practically as old as human communication itself. Its roots and beginnings can be found as far back as ancient times, when usually deliberately constructed and publicly placed, false or erroneous information and news were spread, mostly orally. As Burkhardt (2017) points out, there have been rumors and falsified stories for as long as humans have existed in power-run groups. In the beginning, new information was commonly spoken of person to person (2017: 5). From then until today, various sources and authors have recorded numerous examples of production and dissemination of such information, which is most often called disinformation or a newer popular term - fake news. Terminological issues and views including more detailed explanations of this phenomenon will be discussed later in this paper $^{1}$, with several cases pointed out here, which were marked throughout history as important or significant.

According to Burkhardt (2017), writing first appeared several thousand years ago on materials such as stone, clay, and papyrus, and the information was usually limited to group leaders, e.g., emperors, pharaohs, religious and military leaders, etc. (2017: 5). This power was used by selected persons in various ways, including control of information, spreading of influence, as well as producing and publishing fake news and information in order to achieve a set goal. One of the first recorded 
Disinformation in the New Media System - Characteristics, Forms, Reasons...

cases dates to the $6^{\text {th }}$ century B.C., when Procopius of Caesarea, the principal historian of Byzantium, in his treatise called Secret History (reprint 1961), presented false information denigrating Emperor Justinian and his wife after their death, probably in an attempt to ingratiate the new ruler (Burkhardt, 2017: 5). Posetti and Matthews (2018: 1) in turn believe that "misinformation, disinformation and propaganda have been features of human communication since at least the Roman times when Antony met Cleopatra". It was in ancient Rome that the first of a total of more than 50 significant historical events took place, which Posetti and Matthews chronologically ranked in their "selected timeline of 'information disorder' through the ages" (2018: 2-16). Around 44 B.C., after the assassination of Julius Caesar, Octavian used a smear campaign in the form of short, sharp slogans, based on false and fictitious information and imprinted them on Roman coins, to discredit his opponent Mark Antony. Octavian managed to win this "disinformation war" becoming the first Roman emperor Augustus. In other words, "fake news had allowed Octavian to hack the republican system once and for all" (Kaminska, 2017). In the following centuries and millennia, misinformation continued to be used on many occasions for political and war purposes.

Many authors mark the invention and the implementation of the printing press from the middle of the $15^{\text {th }}$ century onwards as a turning point for raising this problem to a higher level. Posetti and Matthews thus point out: "The invention of the Gutenberg printing press in 1439 dramatically amplified the dissemination of disinformation and misinformation" (2018: 1). Namely, this is when the continuous reproduction and distribution of disinformation in writing started, which also allowed it stronger influence, longer duration, and greater reach. The tragic event that Soll (2016) describes as the first officially recorded case of fake news also originates from that period. On Easter Sunday, 1475, a two-and-a-half-year-old child disappeared in the Italian city of Trento, after which the Franciscan preacher Bernardino da Feltre held several sermons in which he claimed that members of the Jewish community abducted and killed the boy, exsanguinated and drank his blood during the Jewish Passover celebration (Soll, 2016). The rumors spread quickly, resulting in the arrest and torture of numerous members of the Jewish community in Trento and surrounding cities, 15 of whom were found guilty and burned at the stake before the false information was discovered. According to Soll (2016), this and similar fake news have significantly influenced the spread of anti-Semitism in Europe, which is just one of many proofs of how strong, profound, long-lasting and serious the consequences of disinformation can be. The use of false information, propaganda and manipulation of the public through the media became an indispensable segment of all subsequent major war conflicts, and in particular both world wars. For Kunczik and Zipfel (2006: 261), the British-Argentine Falklands War of 1982 is a glaring example, when the British military leadership instrumentalized the media 
by monitoring information and spreading fake news (Cockerell et al., 1984; Morrison and Tumber, 1988). Likewise, along with regular information and news, disinformation began to appear in the public space during peacetime and in other spheres. Thanks to the development of the media, especially mass media such as newspapers, radio and television, untrue information and news are spreading faster, easier and further.

Since it is clear that this is not a recent phenomenon, two questions arise: 1 . Why has disinformation become the focus of the general public in the past few years? and 2. Why do experts in multiple fields, not just media and communications, claim the problem has escalated recently? The answer to the first question is offered by several foreign and domestic authors, such as Posetti and Matthews (2018: 7-9), Tomljenović (2018: 10) and Barton (2019: 1026), who agree that the phenomenon of production and dissemination of disinformation has attracted global attention primarily due to two important events on the political map of the world, in which they played an important, perhaps crucial, role. These are the referendum on the United Kingdom's exit from the European Union (so-called Brexit) in the spring of 2016 and the campaign for the US presidential election followed by the election of Donald Trump as the new president of the United States in the autumn of the same year. Some authors cite the Russo-Ukrainian war (conflict, crisis) as the third important, even earlier event in the same context, which began in 2014 and continues today (Thomas, 2014; Mitrokhin, 2015; Himma-Kadakas, 2017: 26; Posetti and Matthews, 2018: 7). On the other hand, the problem of disinformation in the current digital age and new media system has reached worrying, often dangerous proportions primarily due to the strong development of technology and the emergence of new digital media, owing mostly to the Internet, social networks and communication platforms, as global communication phenomena. As Nougayrede (2018) warns: "The use of propaganda and information fabrication is ancient, but never before has there been the technology to so effectively disseminate it" (as cited in Posetti and Matthews, 2018: 1). Soll (2016) concludes that fake news became a powerful force once again with the appearance of web-generated news, and "yellow journalism" came back into the limelight. According to recent indicators and research, the situation is getting worse, for which there are several other causes and reasons that will be later and briefly explained.

\section{Characteristics of new media and the new media system}

In the last decades of the 20th century, traditional mass media, such as the press, radio and television, were joined by new media and communication means that have special features (Labaš, 2009: 14). New media as their collective name has spread 
Disinformation in the New Media System - Characteristics, Forms, Reasons...

everywhere, and they have an increasing role in social communication and are recording unprecedented development (Riva, 2004: 15). Even today, it is still difficult to draw precise boundaries between the meaning, scope and content of the terms new media and "old media", especially between some of their characteristics, as indicated by Labaš (2009: 14) and Lister et al. (2009: 9-10). For the purposes of this paper, new media is viewed in the context of the explanation given by Logan (2016) in his book Understanding New Media: Extending Marshall McLuhan. According to him, new media "in general refer to those digital media that are interactive, incorporate two-way communication and involve some form of computing" (Logan, 2016: 4). New media "are linked and cross-linked with each other, and the information they mediate is very easily processed, stored, transformed, retrieved, hyperlinked and, perhaps most radical of all, easily searched for and accessed" (Logan, 2016: 7). For Lister et al. (2009: 13) the key characteristics of the field of new media as a whole are digitality, interactivity, hypertextuality, networking, virtuality and simulation, to which Labaš (2009: 16) adds multimedia. In addition, Zgrabljić Rotar also recognizes as important concepts in new media discourse within the current digital culture: mobility, convergence, new audiences, media industry and media revolution (2016: 60). Referring to Paccagnella (2004: 165), Labaš emphasizes that instead of the term new media, several other names and adjectives are sometimes used as its synonyms: cybermedia, multimedia, virtual media, hypermedia, interactive media, digital media and others (2009: 14).

According to Zgrabljić Rotar, there is an extremely diverse new media environment. It consists of digital age media, as she calls them, and it is possible to classify them into the following groups: traditional media, converged media, new media, and new new media (2016: 63). Traditional or classical media and converged traditional media are considered primarily mass media. Converged media have emerged on the Internet platform and allow users to communicate with the media, but they still have the basic features of mass media, and the communication model is still "one-tomany". These are primarily online newspaper portals, radio on demand, television on demand and weblog, i.e., a blog that converged from the former journal (Zgrabljić Rotar, 2016). In other words, traditional mass media such as radio, television and print journalism have reached a new qualitative level and new virtual media (Jabrayilova, 2017: 90) have emerged, i.e., new media expressions uniting their new and old features (Zgrabljić Rotar, 2016: 60) thus representing a combination of mass media and new media. In addition to converged mass media, "pure" new media (for example, e-mail, video games, World Wide Web, and others) have emerged changing the paradigm of traditional "one-to-many" into "one-to-one" communication (Zgrabljić Rotar, 2016: 63). At the end of the $20^{\text {th }}$ and the beginning of the $21^{\text {st }}$ century, the development of a new generation of new media followed, for which Levinson (2013) and Zgrabljić Rotar use the simple term new new media, while some 
other authors, such as McLean (2014), collectively refer to them as contemporary media. This new media group also rests on the Internet platform, but one of its main features is that their users are simultaneously producers and consumers of media content, the so-called prosumers. The form of communication is "many-to-many" (Zgrabljić Rotar, 2016: 64). This category primarily includes social networks, communication platforms and social networking (mobile) applications - e.g., Facebook, Instagram, YouTube, Twitter, Whatsapp, Viber and others (Levinson, 2013: 12) which, along with the Internet, are the focus of this paper. To simplify the terminology for all the listed media groups, aside from traditional mass media, the umbrella term new media is used collectively and is generally accepted.

It has already been mentioned that new media are based on the development of the Internet, and Skoko claims the same (2006: 251). Castells (2003) describes the current form of the Internet as a global network of computer networks that the World Wide Web, an application at the top of the Internet hierarchy, makes easy for the user to use (Castells, 2003: 19). Therefore, Maldini considers the Internet "the network of all networks" (2016: 105), and Malović goes a step further, calling it "the medium of all media" (2007: 14). The Internet is, therefore, the foundation of the emergence and development of several dozen new media forms and types, as far as media and communication theorists currently distinguish them. Together, they are indispensable parts of the modern global new media system, a term that is in a slightly expanded form - new media ecosystem - accepted in official bodies, institutions, and documents of the European Union.

\section{The role of big data in the new media (eco)system}

The term new media ecosystem in the modern age "encompasses institutional (typically newspapers, radio, and television), meso (communication across interconnected peer-to-peer networks, across neighborhoods, and broader community segments), and micro forms (e.g., social media, interpersonal networks) of communication, and is the primary context in which citizens are affected by politics, day to day events, community issues and events such as natural disasters" (Napoli et al., 2012: 5). In this environment, as Car and Matas (2019) point out, with the increase in the number of users, social networks began to generate endless and diverse amounts of information and data (often personal) that users provide every day, leaving behind a "digital trace". Each post, comment or "like" leaves a record on individual users, their preferences and expressed attitudes, and all data collected in this way are stored in a big database on social network and social media servers (Car and Matas, 2019: 107-108). Big data refers to data whose amount of digital information exceeds the storage and processing capacity of a conventional data system (Dumbill, 2013: 1), and are created by leaving digital traces on digital platforms. More impor- 
Disinformation in the New Media System - Characteristics, Forms, Reasons...

tantly, these are interconnected data that carry links to an entire range of other information (Car and Matas, 2019: 108). By extracting available information from big data and their analysis, useful insights can be obtained, but also goods and services that have significant financial, social, or political value (Mayer-Schönberger and Cukier, 2013: 10).

The application of big data technology for the collection, processing, and analysis of large amounts of data within the new media system has greatly changed global political and economic tendencies, including business models of Internet social networks. For example, developing software for analytical calculations on social networks has enabled microtargeting, i.e., directing the desired messages to targeted stakeholders, recognized as receptive audiences for exactly such offered content or services (Nield, 2017). Many abuses of this development have already been noticed, and one of the most famous examples of scandals is related to the most popular social network Facebook and the then British consulting and analytical company Cambridge Analytica (CA). Namely, in the spring of 2018, it became known that CA had obtained the unauthorized personal data of over 87 million Facebook users two years earlier (Curtin, 2018). These citizens were then targeted when marketing political messages during the Brexit referendum and the 2016 U.S. presidential election campaign, which is believed to have had an impact on results of each $^{2}$.

In addition to the above, there are other side effects in modern social communication, with larger or smaller consequences and reach. A document, entitled Council conclusions on media literacy in an ever-changing world, warns, among other things: "Alongside the numerous advantages and positive effects of the new media ecosystem, it has also brought increasing amounts of disinformation, manipulation and hate speech." (The Council of the European Union, 2020: 1).

\section{Precursors, definitions and forms of disinformation and related phenomena}

The phenomenon that is the central theme of this paper has had several direct or indirect historical predecessors, and most of the media literature emphasizes two main ones whose roots go deep into the past of mankind. Burkhardt (2017: 5) and Maret (2018: 245) believe that the first such phenomenon is rumors. Rumors are defined as "talk or opinion widely disseminated with no discernible source", or later on as "a statement or report current without known authority for its truth" (Merriam-Webster's Dictionary, 2020). For Pratkanis and Aronson the true problem arises when unconfirmed rumors are repeated by the media, lending them the illusion of respectability (2001: 2), which unfortunately is a regular occurrence. Another phenomenon in the media sphere is known as the "journalistic duck" or 
canard. The literal translation of this French word into English is "duck", but it is used here in a figurative sense. According to Kovačević (2018: 22), in this context, "journalistic duck" or canard means untrue or fictional newspaper news or story. Merriam Webster's Dictionary (2020) explains similarly, stating that canard is "a false or unfounded report or story", but also "a groundless rumor or belief". The radio and television lexicon slightly expands these definitions by claiming that it is unverified, mostly inaccurate news or information launched with the intent to provoke the effect of a sensation about a person or event that would otherwise go unnoticed in public (Galić, 2016: 357).

There are several different explanations - etymological, communicative, media and other - about how and when the term originated and why a deliberately published lie is called a "journalistic duck" or canard. Its first interpretation in the sense of "false news" was recorded in mid-18 ${ }^{\text {th }}$ century (Kovačević, 2018: 22-23). More important, however, is that the entry of this once popular journalistic genre into the realm of fake news was originally categorized as entertainment, satire or parody. It was geared towards amusement or instructing the unwary (Burkhardt, 2017: 7). Namely, for a long time, all such news and information were clearly marked at the end of the text because the editors and journalists did not want to deliberately mislead their readers. According to Darnton (2017), the first canards were published in the $17^{\text {th }}$ century in French newspapers. This light version of fake news retained its original form for over 200 years in France and other countries, mostly in Germany and England. However, when engravers put Marie-Antoinette's face on copper plates during the French Revolution, the form entered a new phase, that of intentionally fake political propaganda (Darnton, 2017), as "the revised image was used to disparage the queen" (Burkhardt, 2017: 6). Today, fake and fictional news and information are generally no longer labeled (with the exception of satire or parody), and their numbers and public presence have multiplied, given that, as Burkhardt warns (2017: 7), several turnabouts helped increase the creation and dissemination of this kind of information. At the same time, the number of more or less closely related terms denoting this phenomenon has also increased.

\section{Terminological similarities and differences}

Without a doubt, the best known and most used term in this area globally is fake news. Its popularity was mostly contributed by Donald Trump, the $45^{\text {th }}$ United States president, who began using it publicly in 2016, during his first campaign in the US presidential election. Posetti and Matthews (2018: 9) note that in his public appearances as presidential candidate and, even more, in his posts on social networks, especially Twitter, he repeatedly called out and accused political opponents and, in 
Disinformation in the New Media System - Characteristics, Forms, Reasons...

particular, the media who criticized him, of spreading fake news intending to defame him. Pengelly (2016) states that among the first media outlets to be hit by Trump's public verbal and written confrontations was the famous television station CNN (Cable News Network). His posts were and still are very well followed, transmitted and commented on. Trump's rhetoric was soon picked up by many other politicians and authoritarian leaders around the world, so the term "fake news" quickly spread during 2017, for the purpose of political defense (Galvin, 2017). Thus, in July and August 2017, Venezuelan President Nicolas Maduro described foreign media, particularly the BBC and CNN, as "fake news" and "manipulators of information" (cf. Posetti and Matthews, 2018: 10; SputnikNews, 2017). On the other hand, few of Trump's opponents have been spared as he has continued to behave similarly during his presidency. For example, according to the online archive of all his posts on Twitter, just in September 2020, during the new election campaign for his second presidential term, Trump used the phrase "fake news" as many as 35 times, i.e., on average more than once a day (Trump Twitter Archive, 2020). In recent publications, Trump has already replaced the term "fake news" 3 with a new, even stronger phrase, "corrupt news", and his main target is again various media.

Parallel to the spread and increased use of this term, the need for its expert definitions and explanations grew, of which there were already many. Shu and associates opted for a simple definition: "Fake news is a news article that is intentionally and verifiably false" (Shu et al., 2017: 23), to which Allcott and Gentzkow add "and could mislead readers" (2017: 213). According to Rose, fake news are "wholly or mostly fabricated stories in the style of news reports usually posted online and often shared virally" (Rose, 2017: 556). Leonhardt and Thompson (2017) provide a more comprehensive explanation: "Fake news is a type of yellow journalism or propaganda that consists of deliberate misinformation or hoaxes spread via traditional print media, broadcast news media or online social media. Fake news is written and published with the intent to mislead in order to damage an agency, entity, or person, and/or gain financially or politically, often using sensationalist, dishonest, or outright fabricated headlines to increase readership, online sharing, and Internet click revenue." Even though the term "fake news" has in the meantime found its place and some recognition in scientific discourse, in recent times a significant number of media and communication experts are increasingly advocating that this phenomenon be defined differently and more precisely. The first reason lies in the "fake news" coin itself, which some authors consider inappropriate because it is an oxymoron. Namely, Bobić (1987) points out, truthfulness is the very meaning of informing. If it does not contain the truth, the news is meaningless and unnecessary (1987: 17). That is, as Malović (2005) succinctly says: news is either true or not news (2005: 19). Other authors believe that the term "fake news" is overly broad and insufficiently clear. According to Weedon, Nuland and Stamos (2017: 4), it be- 
came a "catch-all phrase to refer to everything from news articles that are factually incorrect to opinion pieces, parodies and sarcasm, hoaxes, rumors, memes, online abuse, and factual misstatements by public figures that are reported in otherwise accurate news pieces" (as cited in Maret, 2018: 245). The third group of authors is of the opinion that the term "fake news" simplifies, even trivializes this large, serious problem, especially if and when it is applied incorrectly. A good example is when politicians use the phrase "fake news" exclusively to publicly disqualify any opposing opinion or position, as Trump has been doing continuously for years.

For these reasons, in the last few years, several potential alternative terms have been proposed to label this phenomenon, and only those that have been officially accepted so far or are most often mentioned and commented on in public space are briefly listed and explained here. Indicatively, the first such term, alternative facts, was uttered precisely from the ranks of the Trump administration and was done by Senior White House aid Kellyanne Conway in January 2017 on the American national television company NBC. Defending an untrue statement of the president's press secretary Sean Spicer about the record number of visitors to Donald Trump's inauguration, she replied that these were not lies but "alternative facts" (The Guardian, 2017). This syntagm - like its derivative alternative truth - has provoked numerous reactions and debates and often appears in public discourse, but it has never really become satisfactory for naming this phenomenon. Himma-Kadakas (2017) explains that the term "alternative facts", as well as "fake news", is controversial and ambiguous, explaining: "The definition in journalistic approach is that the fact is always proven, checked and therefore true - anything alternative to this cannot be treated as a fact" (Himma-Kadakas, 2017: 26). It is similar with another concept, false information or fake information. According to Herman and Chomsky (2008), false information about important things either lie or hinder the expression of an unpleasant truth, in order to gain unconditional support for state or corporate interests. However, Jacquette concludes, false information is not really information, nor is it news, even if published as such (2007: 33). Therefore, the use of this term has remained primarily colloquial and nonscientific.

Among labels that have, to a greater or lesser extent, been accepted by scientists and experts in this regard, some originated even before the issue escalated in the 2010s. One of them is information pollution, which was coined in 2002 and first publicly presented by Paek-Jae-Cho, former CEO cum president of Korean Telecommunication Corp. (KTC). Ramesh Pandita (2014) states that Paek-Jae-Cho then referred to information technology byproducts, including the unwanted impact it had over society seen as information pollution or, in short - infollution. In the modern sense, "information pollution is broadly referred as an outcome of information revolution, wherein people are supplied with contaminated information, which is of less importance, irrelevant, unreliable, and unauthentic, which lacks exactness and precision, 
Disinformation in the New Media System - Characteristics, Forms, Reasons...

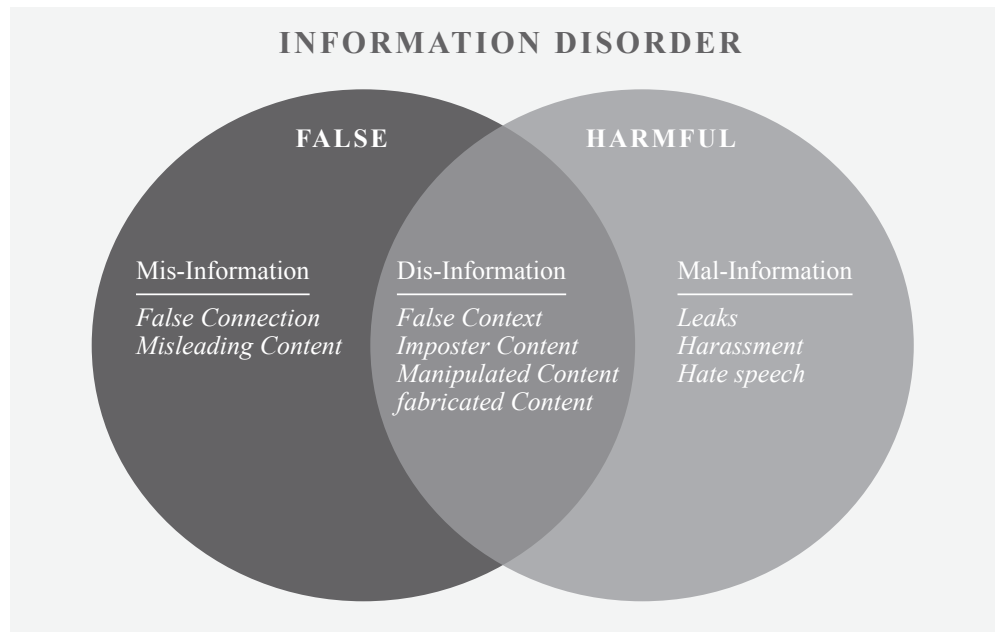

Figure 1. Intersection of three types of information disorder around the concepts of falseness and harm

Prikaz 1. Preklapanje triju tipova informacijskoga poremećaja oko koncepata neistinitosti i štete

Source: Wardle and Derakhshan (2017)

which always has an adverse effect on society at large" (Pandita, 2014: 51). There are several sources of "information pollution", but the new media are prevalent. On the other hand, the term information disorder has only recently been presented in public, in a Council of Europe Report Information Disorder: Toward an interdisciplinary framework for research and policy making published by Wardle and Derakhshan in September 2017. They claim it is important to differentiate true from false messages, and those intended to do harm from those with no such intentions (Wardle and Derakhshan, 2017: 20). Accordingly, they differentiate between "three types of information disorder:

- Dis-information - information that is false and deliberately created to harm a person, social group, organization or country;

- Mis-information - information that is false, but not created with the intention of causing harm;

- Mal-information - information that is based on reality, used to inflict harm on a person, organization or country." (Wardle and Derakhshan, 2017: 20).

As can be seen in these brief descriptions and in Figure 1, most attributes of "information disorder" - the most important ones for this paper - coincide with the central term disinformation. Although it is also an older term in media history, it has re- 
cently been officially adopted at the level of the European Union for the purpose of denoting this phenomenon as it is currently considered the best and most technical. Among other things, as Tomljenović (2018: 12) states, the European Commission established a High-Level Expert Group (HLEG) on fake news and online disinformation in the fall of 2017. HLEG avoids using the term "fake news", because its members think that it is not adequate in explaining this complex phenomenon regarding disinformation (Tomljenović, 2018: 12). The official definition of the term disinformation, as given in the European Commission policy paper Tackling online disinformation is: "Disinformation is verifiably false or misleading information created, presented and disseminated for economic gain or to intentionally deceive the public. It may have far-reaching consequences, cause public harm, be a threat to democratic political and policy-making processes, and may even put the protection of EU citizens' health, security and their environment at risk" (European Commission, 2020). The explanations of disinformation presented are closest to the chosen approach in this paper, where the mentioned problem is primarily observed and processed in the sense of intentionally placed and verifiably inaccurate information produced and disseminated for various purposes, most often for propaganda or manipulation purposes. Therefore, the term disinformation is preferred in this paper as well, although, with regard to other sources and authors, other substitute terms are used in some places, usually in the same or very similar sense.

\section{Types of disinformation and its "close cousins"}

Given the complexity of the phenomenon, several classifications of the forms, types and "close cousins" of disinformation and related concepts are in circulation today. One well-known classification of such content - the three types of information disorder by Wardle and Derakhshan (2017) - has already been presented earlier. Furthermore, Allcott and Gentzkow distinguish their six close cousins from "classic" fake news: "1) unintentional reporting mistakes; 2) rumors that do not originate from a particular news article; 3 ) conspiracy theories; 4) satire that is unlikely to be misconstrued as factual; 5) false statements by politicians; and 6) reports that are slanted or misleading but not outright false" (Allcott and Gentzkow, 2017: 214). That was the basis for many subsequent categorizations and reviews by other analysts. Claire Wardle later elaborated on her initial classification in the oft-cited publication Understanding Information Disorder, which came out in October 2019. According to her, there is a total of seven types of mis-information and dis-information and she considers them a spectrum in which categories are found on a continuum from "low harm" to "high harm" (Wardle, 2019: 12), in this order: 1) satire or parody - there is no harmful intent but there is a potential to deceive; 2) false connection - using titles, images or captions that are not in accordance with the content; 
Disinformation in the New Media System - Characteristics, Forms, Reasons...

3) misleading content - twisting information in such a way as to give a specific view of an issue or person; 4) false context - sharing true content but within a fabricated context; 5) imposter content - impersonating real sources; 6) manipulated content - manipulating true information or visuals in order to deceive; and 7) fabricated content - generating completely false new content, in order for deceitful and harmful purposes (Wardle, 2019: 10-11). Of course, as various types and kinds of false information have been recorded, various motives, causes and reasons for their production and dissemination have also been detected.

\section{Motives, causes and reasons for production and dissemination of disinformation}

It is difficult to summarize in one place all that can be a potential precondition and the reasons individuals, institutions and other stakeholders in the new media system are prompted to design, produce and disseminate disinformation and their 'cousins' in the digital age. However, searching through theory, empirical research and practical examples, a number of factors that are regularly repeated have been singled out.

For Allcott and Gentzkow (2017) there are two key motivations for providing fake news: financial and ideological. In the first case, users who notice certain disinformation often click on the original website, whereby its authors automatically make money from advertising (2017: 217). There is a well-known example from 2016, when on the eve of the US presidential election it was revealed that in Veles, Macedonia, a group of teenagers launched over 100 websites (according to other sources, more than 140) used for targeted production of false information predominantly in favor of Donald Trump, thus earning tens of thousands of dollars (Subramanian, 2017). The second, ideological motivation, in turn, implies that producers use disinformation to try to increase support for political options, candidates, and ideas they favor (Allcott and Gentzkow, 2017: 217). To illustrate, after the Brexit referendum, a lot of proven false and misleading information was identified, which was deliberately spread on social media and communication platforms by proponents of Britain's exit from the European Union and thus probably influencing the outcome of the referendum (Reid, 2019). Similar to the previous classification, Wardle believes that disinformation is "motivated by three distinct factors: to make money; to have political influence, either foreign or domestic; or to cause trouble for the sake of it" (Wardle, 2019: 8). Here we should also recall the position of the European Commission (2020) that disinformation is created for profit or to intentionally deceive the public. When it comes to causes and reasons for the production and dissemination of disinformation, only the most frequently observed and recognized are listed in this paper, due to limited space. 
They primarily include phenomena that are, in simple terms, immanent to human nature and could collectively be subsumed under the term "psychosocial characteristics of persons". Namely, disinformation producers count on the fact that "people are attracted to gossip, rumor, scandal, innuendo ${ }^{4}$, and the unlikely" (Burkhardt, 2017: 8). Psychologist Andrea Vranić (2020) adds that three psychological factors are primarily the "fertile ground" for accepting and further spread of fake news: 1) belief bias - the tendency of people to agree with what is in line with their belief or ideology, 2) cognitive laziness - the reluctance to think and analyze what was heard and read, and 3) feelings. Disinformation is often emotionally arousing, provocative and more likely to grab limited human attention (Vranić, 2020), whether it includes enthusiasm, anger or disappointment. Above all, people are social beings, and accepting someone's views, including fake news, can lead to social support - a sense of belonging and acceptance by people and the society they live in (Vranić, 2020). This is built upon by the phenomenon of selective perception of media content, which was described by Lazarsfeld, Berelson and Gaudet in their research study The People's Choice in 1944. They found that during the then US presidential campaign, voters primarily accepted the arguments of the party close to them (Lazarsfeld, Berelson, \& Gaudet, 2005). Disinformation works on the same principle today, targeting the views of certain users. Maldini (2008) notes that trust is also a fundamental cognitive concept (2008: 155), and distinguishes three levels of trust: personal level, general level and institutional-political level, i.e. trust in institutions and political power actors (2008: 157). The last level, also called trust in social institutions, is the most important for this topic, and several relevant sources record the long-term trend of its decline, which has continued in recent years. The Edelman Trust Barometer from 2020 shows that the world's population have a significant lack of trust in the four observed institutions - civil society organizations, businesses, governments and the media. In that, the confidence index is the lowest for the media and governments (Edelman, 2020: 9). It is worrisome that as many as $61 \%$ of respondents marked the category "a person like yourself" as a very or most credible source, and only $36 \%$ of them marked the category "journalist" (Edelman, 2020: 63). In other words, people prefer to be informed by mere acquaintances and contacts on social networks, only on the basis of their similarity to themselves - that is, lay people as compared to experts, which opens the door to alternative sources of news and, often, disinformation.

Also, two other globally widespread phenomena contain a strong psychosocial component: belief in conspiracy theories and political orientation/polarization. According to Keeley (1999), a conspiracy theory is "a proposed explanation of some historical event (or events) in terms of the significant causal agency of a relatively small group of persons - the conspirators - acting in secret" (1999: 116). Allcott and Gentzkow (2017) warn that it is hard to verify conspiracy theories as true or 
Disinformation in the New Media System - Characteristics, Forms, Reasons...

false, and they are usually originated by people who believe they are true (2017: 214). Some of the most widespread conspiracy theories, also perceived as a branch of disinformation, deal with the belief that vaccination causes autism (from which the whole "anti-vaccine" movement grew), that global warming is a fabrication, and that airplanes deliberately leave chemical traces in the sky that harm humans (chemtrails). The results of several studies suggest that a more extreme political orientation is probably related to a likelihood of spreading disinformation due to a stronger tendency to denigrate political rivals. For example, Silverman and associates conducted an analysis in 2016, which demonstrated that in the studied period, a total of six US political Facebook pages - three right-wing and three left-wing continuously shared a number of false and misleading information with a political overtone. In this context, we should mention the long-begun complex process of globalization, which Maldini (2008) describes as the spread and interpolation of identical or similar social structures, patterns, values and norms in other social spaces (2008: 220). In the $21^{\text {st }}$ century, this also includes the globalization of information and communication means and messages (Gavranović, 2011: 136), at the center of which is the Internet. This has certainly become a catalyst for the spread of disinformation, especially in the "post-truth" age. It is not a new term, but in the modern sense the term "post-truth" was initially used by Ralph Keyes in his book The PostTruth Era, published in 2004. Rose (2017) sees today's world as the age of "posttruth politics" - a world in which public attitudes are more important than the truth, and in which everyone owns their own "facts" (2017: 556) that Maret calls "postfacts" (2018: 243). According to Harsin (2015), a regime of post-truth or as other authors emphasize, a post-truth society is in force.

\section{Reasons and causes of disinformation in new media}

Such a situation has given rise to a number of reasons and causes for producing and disseminating disinformation, particularly typical of the new media system. The introduction of the paper already mentioned the rapid development of technology and the emergence and multiplication of the number and types of new, digital media. The case of Cambridge Analytica, on the other hand, showed what the negative side of the application of big data and microtargeting technology could look like. These tools can also be abused to spread false and unverified news and data. The faster and stronger dissemination of information, and consequently disinformation, is greatly influenced by the mentioned new media characteristics such as digitality, interactivity, hypertextuality, networking, virtuality, multimedia, mobility, and media convergence. However, perhaps the most important was the change in the communication paradigm from the former one-way to today's two-way communication, in which all users actually become prosumers, with the crucial difference being that 
the source of information is now usually incontrollable and unverifiable. Of course, the multiplication of problems regarding disinformation is also facilitated by the constant growth of users of social networks., applications and communication platforms. According to the global data platform Statista, Facebook had more than 2.7 billion users in October 2020, YouTube and Whatsapp over two billion, Facebook Messenger about 1.3 billion, Instagram 1.158 billion, Snapchat around 433 million, Pinterest about 416 million, Twitter around 353 million users, etc. (Statista, 2020). The number of followers is on a constant increase, and Zgrabljić Rotar states that even newer new media are continuously emerging and finding numerous users (2016: 64). For example, currently extremely popular among young people in the world is the Chinese application TikTok, which has already attracted almost 700 million users (Statista, 2020). Furthermore, many citizens continuing to use digital media as their main sources of news is a big problem. The findings of the Reuters Institute Digital News Report for 2019 show that more than half of the combined sample of citizens (55\%) prefer to access news via search engines, social media or news aggregators, where large technology companies typically use algorithms instead of editors to select and story ranking (Newman et al., 2019: 13). For one, "algorithms that create news feeds and compilations have no regard for accuracy and objectivity" (Soll, 2016), which is dangerous. At that, social media algorithms confine users to "echo chambers" and "filter bubbles". These are phenomena where online algorithms filter information based on previous search queries, allowing for potential creation of "bubbles", where a person is only experiencing their own stances and opinions, and all dissenting ones are excluded or minimized (Tomljenović, 2018: 9). It is, thus, technically possible to filter media content (primarily data, information and news) based on user preferences (Domingo, 2008: 687). Such closed circles largely lead to a person receiving only information that corresponds to his or her attitudes and beliefs, which in turn prevents critical approach and thinking.

The production and dissemination of disinformation in the new media system is also contributed to by the fact that fake internet news and rumors, much like illnesses and infectious diseases, are shaped and transmitted through social contacts, in this case through social networks (Kucharski, 2016: 525), which is why they are often defined as viral. The current situation is further aggravated by another fact: false information is simply adopted and spread faster and retained more permanently than the truth. Among the first to prove this was a large-scale new survey conducted in 2016 by Ipsos Public Affairs for BuzzFeed News. Vranić (2020) points out that a comparison of the dissemination and commentary of the 20 biggest fictional news (about 8.7 million shares) compared to the 20 most important accurate news about what really happened (about 7.3 million shares), in just the last three months of the 
Disinformation in the New Media System - Characteristics, Forms, Reasons...

previous US presidential election campaign, showed significantly greater penetration of disinformation (Silverman and Singer-Vine, 2016).

Almost all the above motives, causes and reasons for the production and dissemination of false or unverified information and news are noticeable in the current COVID-19 pandemic. The World Health Organization (WHO) even coined a new term, infodemic, to describe the "flood" of information about the disease, among which it is often difficult to distinguish true from false information. A disinfodemic version was soon coined as well, precisely to draw attention to the numerous disinformation and conspiracy theories that, in connection with the COVID-19 pandemic, had emerged and spread in the public eye (World Health Organization, 2020). They particularly affected those areas of society where disinformation already reaps the most dangerous and severe consequences: health, politics, security issues and the economy. The European migration crisis, which is the official name for the longterm migration of inhabitants of African and Asian countries to EU states, which has been going on since 2015, also stands out from the current major examples. Representatives of the EU and local authorities have repeatedly publicly appealed for a cessation of the production and spreading of disinformation against migrants that cause panic, fear and hatred in the local population, but without tangible results, so most migrants are still exposed to physical attacks, reports and insults.

\section{Existing and potential means and measures to identify and tackle disinformation}

The previously presented cross-section of this serious global problem and the currently escalating situation, does not arouse strong optimism when it comes to quality solutions in the near future. However, in recent years, actors from various social spheres have already adopted and developed several means and measures to recognize and combat the production and dissemination of disinformation. As for recognizing false information in public space, perhaps the most famous is the How to Spot Fake News infographic, which was designed and published in October 2017 by the International Federation of Library Associations and Institutions (IFLA). The infographic contains eight useful tips, i.e. simple steps to discover the verifiability of published content: 1) consider the source; 2) read beyond (the headlines); 3) check the author; 4) (find) supporting sources; 5) check the date; 6) (answer) is it a joke?; 7) check your biases; and 8) ask the experts (IFLA, 2017). In 2018, the Croatian Association for Communication and Media Culture supplemented these steps in a handbook entitled Family and the Challenges of New Media with a total of ten tips on recognizing fake news. In relation to IFLA's infographic, there are several new items and instructions for users: check the domain and layout of the website that 
published the news; check the impressum (information on owners, editorial staff, journalists); check out questionable quotes and photos and, most importantly - think before you further share the news (Ciboci et al., 2018: 37). Media experts especially point out that if information caused strong emotions of any kind, as a rule, its veracity should be doubted and further verified.

Regarding tackling disinformation, several already existing means and measures are presented here, including proposals for potential means of combating it, as well as recommendations and proposed guidelines for a more effective fight against false content. Following the example of Haciyakupoglu and associates, this paper advocates a combination of legislative, regulatory and non-legislative measures, i.e., a multi-pronged approach that can provide a more comprehensive way of fighting fake news. The broad framework in countering fake news includes three kinds of measures - pre-emptive, immediate and long-term (Haciyakupoglu et al., 2018: 14). The means and measures presented here can be roughly divided into preventive, proactive and reactive:

- Developing precise computer algorithms for recognizing, blocking and deleting disinformation. Mohseni and Ragan (2018) point to the dual nature of algorithms that can be both a problem (for example, "filter bubbles" and "echo chambers") and one of the solutions. On the one hand, news feed algorithms can be misused to spread and promote falsified content, affect news diversity, or impact credibility. On the other hand, algorithms detecting fake news attempt to combat problems by identifying disinformation and fraudulent user profiles (Mohseni i Ragan, 2018: 1). Large social networks have been making efforts for years to develop the latter type of algorithms. Specifically, between March and June 2020, more than 7 million posts containing disinformation about the current COVID-19 pandemic were deleted from Facebook and Instagram (Washington Post, 2020). The problem is that artificial intelligence (AI) is still not at a high enough level to be able to differentiate true information and news from fake with minimal error. Aside from that, Renda (2018) claims, relying solely on the algorithmic content removal is a threat for freedom of expression (2018: 17). Therefore, in the summer of 2018, Facebook also hired a number of human moderators who check the accuracy and veracity of the posts in combination with algorithms.

- Increasing the number and quality of fact-checkers. Fact-checkers are not a recent phenomenon as they were first recorded a hundred years ago in the United States (Vilović, 2007: 118). However, their mass appearance began in the 2010s, with the term fact-checkers referring to Internet platforms, (often non-profit and non-governmental) organizations and persons in charge of verifying the accuracy of information published in public, primarily in the 
Disinformation in the New Media System - Characteristics, Forms, Reasons...

media. According to the October 2020 Duke Reporters' Lab, there are almost 300 registered fact-checkers in 84 countries on six continents, the most famous being the American PolitiFact and the British Full Fact. Fact-checkers are conceived as a corrective to the actions of the media and are signatories to the Code of Ethics and should be independent and objective. Their biggest objections concern the alleged political bias in selection and verification of articles. Nevertheless, fact-checkers are certainly useful, and society should persevere in their further development, especially since there are still not enough of them for quality monitoring and coverage of media content. For example, the only fact-checker in Croatia is the Faktograf.hr portal, Facebook's official partner in detecting disinformation.

- Creating and adopting new and adjusted legal and media regulations. In this respect, the European Union has done insofar, trying to establish effective regulation. Therefore, several important documents and legal acts aimed at solving this problem have already been adopted, including The Code of Practice on Disinformation, "the first worldwide self-regulatory set of standards to fight disinformation, voluntarily signed by platforms, leading social networks, advertisers and advertising industry in October 2018" (European Commission, 2020). It was signed by Facebook, Twitter, Mozilla, Google, Microsoft and TikTok, among others, and in September 2020, its current implementation was assessed as useful and satisfactory (European Commission, 2020). It is expected that at the beginning of 2021, the European Commission will adopt the Digital Services Act, which should more clearly regulate the disinformation issue. However, legislation and media regulations in this area are still deficient and insufficient. This is especially true in Croatia, where the problem of fabricating and spreading fake news is at the moment practically regulated only by the outdated 1977 Law on Misdemeanors against Public Order and Peace, which was last amended in 1994. When adopting new legal acts, it is crucial to ensure that their provisions do not violate or restrict basic human rights, primarily freedom of information, speech and expression as the foundations of a democratic society. The same applies to all other existing and suggested measures.

- Further strengthening the scientific and expert approach to the problem of disinformation. Since 2016, numerous scientific and professional conferences, symposia and meetings have been organized in Europe and the world, many relevant research studies have been conducted and hundreds of scientific papers have been published, helping to understand the global disinformation problem from several aspects - media, communication, psychological, sociological, political science and others. A significant increase in aca- 
demic research interest on this topic is also confirmed by Biloš (2019). His meta-analysis of scientific research, which included a total of 393 papers, indicated that over $88 \%$ were published in the last 5 years (2015-2019), and more than half of the papers were published during 2018 (Biloš, 2020: 170). At the same time, several expert studies, projects and programs have been adopted, such as the Action Plan against Disinformation, which has been jointly implemented by several European Union bodies since December 2018 (European Commission, 2020). Despite the above, lay, populist and often trivial treatment of the disinformation issue is still quite present in the public discourse, which is why it is necessary to continue strengthening the scientific and expert-led approach. Specifically, it is necessary to determine as soon as possible a unified and official technical terminology, definitions and other important components of this complex problem, about which there are still controversies, as shown in this paper.

- Returning to traditional ethical and professional values of journalism. Unfortunately, journalistic ethical and professional values and postulates are some of the biggest victims of the existing new media system and post-truth age. This is an extremely unwelcome but expected consequence of the fact that literally every literate person with access to the Internet can publish information, whether it is accurate and true or not. Editors and journalists have, seemingly irreversibly, lost their former role as "gatekeepers", i.e., persons who decide what and which kind of information will be placed in the public. In the media, the so-called copy \& paste journalism is prevalent. Namely, often certain interesting information appears in one media outlet, and is conveyed by other media uncritically, almost identically and without additional verification (Malović, 2014: 129). In such circumstances, this proposed measure seems difficult to achieve, but great progress would be made if it could be implemented at least in part.

- Increasing the level of media literacy and critical thinking among citizens. Many media experts agree that media literacy is one of the major competencies for life in the $21^{\text {st }}$ century (Tomljenović, 2018: 5). Simultaneously, a methodical and strong development of media literacy, along with critical thinking in citizens, would in the long run be the best and most efficient step for preventing the problem of producing and spreading disinformation. Patricia Aufderheide (1993) stated a basic definition of term "media literacy": „It is the ability of a citizen to access, analyze, and produce information for specific outcomes" (1993: 6). The state of media literacy varies from country to country, and Croatia, according to the results of several measurements, is still among the worst in the EU in this regard. Several organizations and plat- 
Disinformation in the New Media System - Characteristics, Forms, Reasons...

forms in Croatia - like the Association for Communication and Media Culture, the Agency for Electronic Media and medijskapismenost.hr portal - are continuously implementing educational projects and media literacy programs for citizens, especially children and youth. However, media literacy should become an indispensable part of all levels of compulsory educational programs in Croatia, starting with pre-school education, because children encounter the media exceedingly early. This would, among other things, undoubtedly have a positive impact also on the development of self-regulation of journalists, media and citizens and increase the level of their social responsibility as other important factors.

\section{Conclusion}

As shown in this paper, the phenomenon of production and dissemination of disinformation is certainly not new, but many reasons, causes and manners of its origin and development are new, which is why it has grown into a very serious and dangerous global phenomenon in recent years. This old problem has especially escalated in the digital age and the new media system, among other things because - as The Council of the European Union (2020) concludes in its recent report on media literacy - "citizens are overwhelmed with information and have trouble understanding the news and finding accurate information, reliable news sources, as well as quality content in general" (2020: 1). This was most pronounced during the current COVID-19 pandemic, which often had both fatal and tragic consequences. For example, according to research published in the American Journal of Tropical Medicine and Hygiene, in the first three months of 2020 alone, more than 800 people worldwide died and about 5,800 people were hospitalized as a result of believing widespread false information about coronavirus and its treatments (Večernji list, 2020). Thus, disinformation has not ceased to cause death since the 15 th century, when, based on the first officially recorded fake news of a missing and allegedly murdered boy, 15 members of the Jewish community were murdered in Italy.

Disinformation can, of course, have many other negative consequences on the lives and security of citizens and society as a whole, as demonstrated by current examples of Brexit, the Russo-Ukrainian war and the European migrant crisis. Largely due to the strong development of technology and the emergence of new digital media, there is an increasing production and dissemination of false information. Rose (2017) points out that news increasingly becomes something that is consumed over the Internet, and is also increasingly and virally shared, hence the challenge posed by fake news is sure to increase, not diminish (2017: 556). This paper presents a number of already existing means and measures for recognizing and combating 
disinformation, with several new guidelines proposed, emphasizing the very necessary development of media literacy and critical thinking at all levels. The European Commission (2020) highlights: "Fighting disinformation in the era of social media and online platforms has to be a coordinated effort involving all relevant actors, from institutions to social platforms, from news media to single users." In other words, joint action of all social structures is necessary in order to alleviate, if not solve, the problem of disinformation, reducing it to a minimum as soon as possible. It should be noted that this battle includes certain measures and steps, such as the adoption of new and amending existing legislation and media regulations, where there is a danger of encroaching on some fundamental human rights. Thus, the European Convention on Human Rights (Article 10.1.) and the Charter of Fundamental Rights of the European Union (Article 11.1.) prescribe equally: "Everyone has the right to freedom of expression. This right shall include freedom to hold opinions and to receive and impart information and ideas without interference by public authority and regardless of frontiers." (as cited in Renda, 2018: 20). Regarding that, it becomes clear how important it is to strike the best possible balance between creating the necessary legal framework to combat disinformation on the one hand and, on the other, preserving the public's right to accurate and correct information and the right of individuals to freedom of speech and expression.

\section{ENDNOTES}

1 This paper is based on a presentation given by the author of the paper on November 27, 2019 at the Croatian Journalists' House in Zagreb as part of the international conference Tackling disinformation in the era of digital media. The presentation was an introduction into later conference lectures, discussions and round tables on the topic of disinformation in the modern age, thus presenting the basics and framework of this issue, from definitions and scope to how to combat this unwanted phenomenon. It is a blueprint followed in this paper.

2 This huge scandal was followed by lawsuits against Facebook, Cambridge Analytica and the SCL group to which CA belonged. The case resulted in the closure of Cambridge Analytica, while Facebook agreed to pay large fines in the United States and the United Kingdom (Zialcita, 2019).

3 Donald Trump has repeatedly stated that he is actually the author of the term "fake news", but this is not true. Most media theorists and journalists, such as Beaujon (2019), attribute the credit to Craig Silverman, a Canadian journalist and media editor at BuzzFeed News. Beaujon writes: "Silverman first started using the term 'fake news' in the fall of 2014 while he was running a research project at Columbia University's Tow Center for Digital Journalism” (Beaujon, 2019). Two years later, Trump took over and popularized the term.

4 Innuendo - "a distortion, half-truth, outright falsity, or unsupported claim presented as the truth" (Pratkanis and Aronson, 2001: 26). 
Disinformation in the New Media System - Characteristics, Forms, Reasons...

\section{REFERENCES}

Allcott, H. \& M. Gentzkow (2017) "Social Media and Fake News in the 2016 Election”, Journal of Economic Perspectives, 31 (2), 211-236. doi: 10.1257/jep. 31.2.211.

Aufderheide, P. (1993) Media Literacy. A Report of the National Leadership Conference on Media Literacy. Washington: The Aspen Institute.

Barton, C. C. (2019) "Critical Literacy in the Post-Truth Media Landscape", Policy Futures in Education, 17 (8), 1024-1036. doi: https://doi.org/10.1177/ 1478210319831569

Biloš, A. (2019) "Emerging Focus on Fake News Issues in Scientific Research: A Preliminary Meta-Analysis Approach", Interdisciplinary Management Research, 15, 1139-1150. CROSBI ID: 1036464.

Biloš, A. (2020) "Izazovi internetskog informacijskog prostora: kako stanovnici Republike Hrvatske doživljavaju problem lažnih vijesti? (Challenges of Internet information space: How do Croatian citizens perceive fake news issue?)", CroDiM: International Journal of Marketing Science, 3 (1), 166-185. doi: orcid. org/0000-0003-1676-5959.

Bobić, D. (1987) Što s događajem - o umijeću novinskog obavještavanja. Zagreb: Informator.

Burkhardt, J. M. (2017) "History of Fake News", Library Technology Reports, 53 (8), 5-9. https://doi.org/10.1108/JPBM-12-2018-2155.

Car, V. \& G. Matas (2019) "Istraživački pristupi lažnim vijestima - kako uz pomoć big data razotkriti trolove?”, 101-116. In: Hrnjić Kuduzović, Z., M. Kulić \& J. Jurišić (eds.) Vjerodostojnost medija: doba lažnih informacija (zbornik radova 9. regionalne naučne konferencije Vjerodostojnost medija). Tuzla: Filozofski fakultet Univerziteta u Tuzli.

Castells, M. (2003) Internet galaksija: Razmišljanja o Internetu, poslovanju $i$ društvu. Zagreb: Jesenski i Turk.

Ciboci, L., et al. (2018) Obitelj i izazovi novih medija (third supplemented edition). Zagreb: Društvo za komunikacijsku i medijsku kulturu.

Cockerell, M. et al. (1984) Sources close to the Prime Minister: inside the hidden world of the news manipulators. London: Macmillan.

Domingo, D. (2008) "Interactivity in the Daily Routines of Online Newsrooms: Dealing with an Uncomfortable Myth", Journal of Computer-Mediated Communication, 13(3), 680-704. doi: 10.1111/j.1083-6101.2008.00415.x

Dumbill, E. (2013) “Making Sense of Big Data”, Big Data 1(1), 1-2. 
Medij. istraž. (god. 26, br. 2) 2020. (29-58)

Galić, M. (ed.) (2016) Leksikon radija i televizije (drugo izdanje). Zagreb: Hrvatska radiotelevizija, Naklada Ljevak.

Gavranović, A. (2011) Poslovno novinarstvo između etike i zarade. Zagreb: Dnevnik d.o.o.

Haciyakupoglu, G. et al. (2018) Countering Fake News: A Survey of Recent Global Initiatives. Singapore: S. Rajaratnam School of International Studies, Nanyang Technological University.

Harsin, J. (2015) "Regimes of Posttruth, Postpolitics, and Attention Economies", Communication, Culture and Critique, 8 (2), 327-333. doi: https://oi.org/ 10.1111/cccr. 12097.

Herman, E. S. \& N. Chomsky (2008) Manufacturing Consent: The Political Economy and Mass Media. London: Bodley Head.

Himma-Kadakas, M. (2017) "Alternative facts and fake news entering journalistic content production cycle", Cosmopolitan Civil Societies: An Interdisciplinary Journal. 9 (2), 25-40. https://doi.org/10.5130/ccs.v9i2.5469.

Jabrayilova, I. G. (2017) "Superiority and problems of new media", Problems of information society, 2, 90-96. doi: 10.25045/jpis.v08.i2.11.

Jacquette, D. (2007) Novinarska etika: moralna odgovornost u medijima. Beograd: Službeni glasnik.

Keeley, B. L. (1999) “Of Conspiracy Theories”, Journal of Philosophy, 96 (3), 109126. doi: 10.2139/ssrn.1084585.

Keyes, R. (2004) The Post-Truth Era: Dishonesty and Deceipton in Contemporary Life. New York: St. Martin's Press.

Kovačević, B. (2018) “Od A do Ž: Novinska patka, žuta štampa i sedma sila”, Hrvatski jezik, 1, 22-25.

Kucharski, A. (2016) "Post-truth: Study epidemiology of fake news", Nature, 540 (7634): 525. doi: 10.1038/540525a.

Kunczik, M. \& A. Zipfel (2006) Uvod u znanost o medijima i komunikologiju. Zagreb: Zaklada Friedrich Ebert.

Labaš, D. (2009) "Međuljudska komunikacija, novi mediji i etika", 13-40. In: Labaš, D. (ed.). Novi mediji - nove tehnologije - novi moral (zbornik radova s Okruglog stola s međunarodnim sudjelovanjem). Zagreb: Hrvatski studiji Sveučilišta u Zagrebu.

Lazarsfeld, P. F., Berelson, B. R. \& H. Gaudet (2005) The People's Choice: How the Voter Makes up his Mind in a Presidential Campaign. Ann Arbour: UMI.

Levinson, P. (2013) New New Media (2nd edition). Boston: Pearson.

Lister, M. et al. (2009) New Media: a critical introduction, Second Edition. London, New York: Routledge, Taylor \& Francis Group. 
Disinformation in the New Media System - Characteristics, Forms, Reasons...

Logan, R. K. (2016) Understanding New Media: Extending Marshall McLuhan (Second Edition). New York: Peter Lang Publishing Inc.

Maldini, P. (2008) Demokracija i demokratizacija. Dubrovnik: Sveučilište u Dubrovniku.

Maldini, P. (2016) "Network Society and Democracy: How ICT Mediated Communication and Virtual Socialization Affects Political Participation", Communication Management Review, 1 (1), Zagreb, 104-121. https://doi.org/10.22522/ cmr20160106.

Malović, S. (2005) Osnove novinarstva. Zagreb: Golden marketing - Tehnička knjiga.

Malović, S. (2007) Mediji i društvo. Zagreb: ICEJ \& Sveučilišna knjižara.

Malović, S. (2014) "Masovno komuniciranje", 40-132. In: Malović, S. (ed.): Masovno komuniciranje. Zagreb: Golden marketing - Tehnička knjiga, Sveučilište Sjever.

Maret, S. (2018) "The public and its problems: "Fake news" and the battle for hearts and minds", 234-266. In: M. Huff \& A. L. Roth (ed.): Censored 2019: Fighting the fake news invasion. New York: Seven Stories Press.

Mayer-Schönberger, V. \& K. Cukier (2013) Big Data: A Revolution that Will Transform How We Live, Work and Think. London: John Murray

Mitrokhin, N. (2015) "Infiltration, instruction, invasion: Russia's War in the Donbass", Journal of Soviet and Post-Soviet Politics and Society, 1 (1), 219-249.

Mohseni, S. \& E. D. Ragan (2018) "Combating Fake News with Interpretable News Feed Algorithms", ArXiv, 1-8. New York: Cornell University. doi: http://arxiv. org/abs/1811.12349.

Morrison, D. E. \& H. Thumber (1988) Journalists at War. The Dynamics of News Reporting During the Falkland Conflict. London: Sage Publications.

Napoli, P. M. et al. (2012) "Understanding media diversity using media ecosystem analysis: A review of the field and recommendations for a way forward", New America Foundation White Paper, 1-28.

Newman, N. et al. (2019) Reuters Institute Digital News Report 2019. Reuters Institute for the Study of Journalism, University of Oxford.

Paccagnella, L. (2004) Sociologia della comunicazione. Bologna: il Mulino.

Pandita, R. (2014) "Information Pollution, a Mounting Threat: Internet a Major Causality", Journal of Information Science Theory and Practice, 2 (4), 49-60. doi: 10.1633/JISTaP.2014.2.4.4.

Posetti, J. \& A. Matthews (2018) A short guide to the history of 'fake news' and disinformation. Washington D. C.: International Center for Journalists.

Pratkanis, A. R. \& E. Aronson (2001) Age of Propaganda: The Everyday Use and Abuse of Persuasion ( $2^{\text {nd }}$ ed.). New York: Freeman. 
Medij. istraž. (god. 26, br. 2) 2020. (29-58)

Procopius, Secret History (1961) trans. Richard Atwater. New York: Covici Friede; Chicago: P. Covici, 1927; repr. Ann Arbor: University of Michigan Press, 1961.

Riva, G. (2004) Psicologia dei nuovi media. Bologna: Il Mulino.

Rose, J. (2017) "Brexit, Trump, and Post-Truth Politics", Public Integrity, 19 (6), 555-558. doi: 10.1080/10999922.2017.1285540.

Shu, K. et al. (2017) "Fake News Detection on Social Media: A Data Mining Perspective", ACM SIGKDD Exploration Newsletter, 19 (1), 22-36. https://dl.acm. org/doi/10.1145/3137597.3137600.

Skoko, B. (2006) Priručnik za razumijevanje odnosa s javnošću: Knjiga eseja $i$ praktičnih uputa za snalaženje u jednome od najpoželjnijih zanimanja današnjice. Zagreb: Millenium promocija d.o.o.

Thomas, T. (2014) "Russia's information warfare strategy: Can the nation cope in future conflicts?” The Journal of Slavic Military Studies, 27 (1), 101-130. https: //doi.org/10.1080/13518046.2014.874845.

Vilović, G. (2007) Povijest vijesti. Zagreb: ICEJ, Sveučilišna knjižara.

Wardle, C. \& H. Derakhshan (2017) Information Disorder: Toward an interdisciplinary framework for research and policy making. Strasbourg: Council of Europe.

Wardle, C. (2019) Understanding Information Disorder. London: First Draft.

Zgrabljić Rotar, N. (2016) "Novi mediji digitalnog doba”, 57-64. In: Josić, Lj. (ed.): Informacijska tehnologija i mediji 2016 (collection of papers). Zagreb: Hrvatski studiji Sveučilišta u Zagrebu.

\section{Internet sources}

Beaujon, A. (2019) "Trump Claims He Invented the Term "Fake News"- Here's an Interview with the Guy Who Actually Helped Popularize It", Washingtonian, 2 October. https://www.washingtonian.com/2019/10/02/trump-claims-he-invented-the-term-fake-news-an-interview-with-the-guy-who-actually-helped-popularize-it/ (accessed 28 September 2020).

Curtin, M. (2018). Was Your Facebook Data Stolen by Cambridge Analytica? Here $^{e e}$ s the Simple Way to Tell, Inc.com, 11 April 2018. https://www.inc.com/ melanie-curtin/was-your-facebook-data-stolen-by-cambridge-analytica-hereshow-to-tell.html (accessed 8 December 2020).

Darnton, R. (2017) “The True History of Fake News", The New York Review of Books, 13 February 2017. https://www.nybooks.com/daily/2017/02/13/the-truehistory-of-fake-news/ (accessed 23 September 2020).

Duke Reporters' Lab (2020) Fact-checking count tops 300 for the first time, 13 October 2020. https://reporterslab.org/latest-news/ (accessed 15 October 2020). 
Disinformation in the New Media System - Characteristics, Forms, Reasons...

Edelman (2020). Edelman Trust Barometer 2020, 19 January 2020. https://www. edelman.com/trustbarometer (accessed 28 September 2020).

European Commission (2020) Tackling online disinformation. Last update: 7 July 2020. https://ec.europa.eu/digital-single-market/en/tackling-online-disinformation (accessed 25 September 2020).

Galvin, G. (2017) "The Globalization of 'Fake News", U.S. News, 27 December 2017. https://www.usnews.com/news/best-countries/articles/2017-12-30/howfake-news-charges-spread-around-the-globe (accessed 23 September 2020).

IFLA (2017) How to Spot Fake News, October 2017. https://www.ifla.org/publications/node/11174 (accessed 26 September 2020).

Kaminska, I. (2017) A module in fake news from the info-wars of ancient Rome, Financial Times. https://www.ft.com/content/aaf2bb08-dca2-11e6-86ac-f253db 7791c6 (accessed 21 September 2020).

Leonhardt, D. \& S. A. Thompson (2017) “Trump's lies", The New York Times. https://www.nytimes.com/interactive/2017/06/23/opinion/trumps-lies.html (accessed 27 September 2020).

McLean, S. J. (2014) "The Contemporary Media Environment, An Essay", Media Factory, 24 October 2014. http://www.mediafactory.org.au/stephanie-mclean/ (accessed 9 December 2020).

Merriam-Webster's Dictionary (2020) Canard. https://www.merriam-webster.com/ dictionary/canard (accessed 25 September 2020).

Merriam-Webster's Dictionary (2020) Rumor. https://www.merriam-webster.com/ dictionary/rumor\#synonyms (accessed 25 September 2020).

Nield, D. (2017) "You Probably Don't Know All the Ways Facebook Tracks You", Gizmodo. https://gizmodo.com/all-the-ways-facebook-tracks-you-that-youmight-not-kno-1795604150 (accessed 7 December 2020).

Nougayrede, N. (2018) "In this age of propaganda, we must defend ourselves. Here's how", The Guardian. 31 January 2018. https://www.theguardian.com/ commentisfree/2018/jan/31/propaganda-defend-russia-technology (accessed 24 September 2020).

Pengelly, M. (2016) "Trump accuses CNN of "fake news" over reported Celebrity Apprentice plans", The Guardian, 10 December 2016. https://www.theguardian. com/us-news/2016/dec/10/trump-celebrity-apprentice-cnn-fake-news (accessed 27 September 2020).

Reid, A. (2019) "Brexit: The false, misleading and suspicious claims CrossCheck has uncovered so far", First Draft News, 3 October 2019. https://firstdraftnews. $\mathrm{org} /$ latest/brexit-the-false-misleading-and-suspicious-claims-crosscheck-hasuncovered/ (accessed 29 September 2020). 
Medij. istraž. (god. 26, br. 2) 2020. (29-58)

Renda, A. (2018) “The legal framework to address 'fake news': possible policy actions at the EU level", European Parliament, June 2018. https:/www.europarl. europa.eu/RegData/etudes/IDAN/2018/619013/IPOL_IDA(2018)619013_EN. pdf (accessed 9 December 2020).

Silverman, C. et al. (2016) "Hyperpartisan Facebook Pages Are Publishing False and Misleading Information at Alarming Rate", BuzzFeed News, 20 October 2016. https://www.buzzfeednews.com/article/craigsilverman/partisan-fb-pagesanalysis (accessed 29 September 2020).

Silverman, C. \& J. Singer-Vine (2016) "Most Americans Who See Fake News Believe It, New Survey Says”, BuzzFeed News, 6 December 2016. https://www. buzzfeednews.com/article/craigsilverman/fake-news-survey (accessed 29 September 2020).

Soll, J. (2016) “The Long and Brutal History of Fake News", POLITICO Magazine. https://www.politico.com/magazine/story/2016/12/fake-news-history-long-violent-214535?fbclid=IwAR1VY-vzGU1Ofl5zerxFTM7_TrHSdCedxj7mYzs0J1RI5Xwg48r2Jngo_xM (accessed 17 September 2020).

SputnikNews (2017) "Maduro Accuses World Media of Spreading Fake News on Venezuela",27July2017.https://sputniknews.com/latam/201707271055924853maduro-media-fake-news/ (accessed 23 September 2020).

Statista (2020) Most popular social networks worldwide, October 2020. https:// www.statista.com/statistics/272014/global-social-networks-ranked-by-numberof-users/ (accessed 14 October 2020).

Subramanian, S. (2017) "Inside the Macedonian Fake-News Complex", Wired, 15 February 2017. https://www.wired.com/2017/02/veles-macedonia-fake-news/ (accessed 28 September 2020).

The Council of the European Union (2020) Council conclusions on media literacy in an ever-changing world. 2020/C (193/06). https://eur-lex.europa.eu/legalcontent/EN/TXT/PDF/?uri=CELEX:52020XG0609(04)\&rid=9 (accessed 29 September 2020).

The Guardian (2017) "Kellyanne Conway denies Trump press secretary lied: "He offered alternative facts"” (video), 22 January 2017. https://www.theguardian. com/us-news/video/2017/jan/22/kellyanne-conway-trump-press-secretary-alternative-facts-video (accessed 29 September 2020).

Tomljenović, R. (2018) Regulatory Authorities for Electronic Media and Media Literacy: Comparative Analysis of the Best European Practices. Council of Europe. https://rm.coe.int/regulatory-authorities-for-electronic-media/1680903a2a (accessed 30 September 2020).

Trump Twitter Archive (2020) http://www.trumptwitterarchive.com/archive/fake\% 20news\%20\%7C\%7C\%20fakenews\%20\%7C\%7C\%20fake\%20media/ttff/1-19 -2017_(accessed 3 October 2020). 
Disinformation in the New Media System - Characteristics, Forms, Reasons...

Večernji list (2020), ,Stotine mrtvih zbog lažnih informacija o koroni: pili su metanol, sredstva za čišćenje, kravlji urin“, 13 August 2020. https://www.vecernji.hr/ vijesti/stotine-mrtvih-zbog-dezinformacija-o-koroni-pili-su-metanol-sredstvaza-ciscenje-kravlji-urin-1423683 (accessed 30 September 2020).

Vranić, A. (2020) "Fake news: priča o novcu, razumu i tri jokera", Zagrebačko psihološko društvo, 8 April 2020. https://zgpd.hr/2020/04/08/fake-news-pricao-novcu-razumu-i-tri-jokera/ (accessed 27 September 2020).

Washington Post (2020) "Facebook and Instagram removed 7 million posts for COVID-19 misinformation", 11 August 2020. https://www.washingtonpost.com (accessed 29 September 2020).

Weedon, J., Nuland, W. \& A. Stamos (2017) "Information Operations and Facebook", Facebook, 27 April 2017, v.1.0. https://i2.res.24o.it/pdf2010/Editrice/ ILSOLE24ORE/ILSOLE24ORE/Online/_Oggetti_Embedded/Documenti/2017 /04/28/facebook-and-information-operations-v1.pdf (accessed 28 September 2020).

World Health Organization (2020) Call for Action: Managing the Infodemic, 11 December 2020. https://www.who.int/news/item/11-12-2020-call-for-actionmanaging-the-infodemic (accessed 14 December 2020).

Zialcita, P. (2019) Facebook Pays \$643,000 Fine for Role in Cambridge Analytica Scandal, 30 October 2019. https://www.npr.org/2019/10/30/774749376/facebook-pays-643-000-fine-for-role-in-cambridge-analytica-scandal? $t=16085006$ 04374 (accessed 8 December 2020).

\section{Dezinformacije u novomedijskom sustavu - značajke, oblici, razlozi širenja i potencijalni načini njihova suzbijanja}

\section{Tomislav Levak}

\section{SAŽETAK}

Cilj je ovoga rada pojasniti fenomen dezinformacija i njegov utjecaj te ukazati na veličinu i ozbiljnost ovoga problema, kao i na važnost zajedničkoga djelovanja svih društvenih struktura u njegovu rješavanju.

Osmišljavanje i proizvodnja neistinitih i netočnih informacija i vijesti u različite svrhe te njihovo širenje, uglavnom usmenim putem, zabilježeni su još u antičko 
Medij. istraž. (god. 26, br. 2) 2020. (29-58)

doba. Nakon izuma tiskarskoga stroja započelo je njihovo kontinuirano umnažanje i distribucija i u pisanom obliku, što im je ujedno omogućilo jači utjecaj, dulje trajanje $i$ veći doseg. Zahvaljujući razvoju medija, osobito masovnih medija poput novina, radija i televizije, informacije i vijesti širile su sve brže, lakše $i$ dalje, no paralelno sve su se češće u javnom prostoru počele pojavljivati $i$ dezinformacije. Zbog snažnoga razvoja tehnologije i pojave novih digitalnih medija, u prvom redu interneta, društvenih mreža i komunikacijskih platformi, kao globalnih komunikacijskih fenomena, ovaj je problem u aktualnom digitalnom dobu i novomedijskom sustavu poprimio zabrinjavajuće, nerijetko i opasne razmjere. Prema recentnim pokazateljima i istraživanjima situacija se sve više pogoršava.

Premda se u posljednjih nekoliko godina u Europi i svijetu značajno povećao broj znanstvenih radova i istraživanja na ovu temu, riječ je o kompleksnoj i još uvijek nedovoljno obrađenoj problematici u znanstvenom diskursu. Stoga se $u$ ovom radu daje pregledan uvid $u$ definicije $i$ značajke dezinformacija, kao pojma koji je na razini Europske unije službeno usvojen u svrhu označavanje ove pojave, ali i srodnih i bliskih termina kao što su lažne vijesti (fake news), misinformation, malinformation, informacijski poremećaj (information disorder), informacijsko zagađenje (information pollution), alternativne činjenice (alternative facts) $i$ drugi. Pomoću iznošenja odgovarajuće stručne teorijske podloge i rezultata niza relevantnih prethodnih istraživanja, ukratko se prikazuju i povijesni razvoj i poznati slučajevi uporabe dezinformacija te uzroci, razlozi, posljedice i najosjetljivije sfere njihove produkcije i širenja u suvremenom društvu. Predočavaju se $i$ do sada utvrđeni načini za prepoznavanje, prevenciju i borbu protiv dezinformacija, ali i predlažu nove mjere za njihovo suzbijanje.

Ključne riječi: dezinformacije, novi mediji, lažne vijesti, informacijski poremećaj, novomedijski sustav, digitalno doba, suzbijanje dezinformacija 